\title{
МЕТОДИКА НАВЧАННЯ ГІМНАСТИЧНИМ ВПРАВАМ ШКІЛЬНОÏ ПРОГРАМИ
}

\author{
Доцент, кандидат педагогічних наук О.В. Іващенко \\ Харківський державний педагогічний університет \\ ім. Г.С. Сковороди
}

\begin{abstract}
На ефективність навчання руховим діям суттево впливає вибір і використання методів навчання. Під методом розуміється спосіб вирішення завдань, пов'язаних з навчанням. Далі зупинимося на характеристиці методів навчання в гімнастиці.
\end{abstract}

\section{Методи навчання (характеристика)}

Словесний метод. Це один з універсальних методів, з допомогою якого вирішуються такі задачі, як: опис техніки, постановка задач навчання, аналіз результатів виконання рухів, керівництво навчання. В гімнастиці використовуються різноманітні методичні прийоми, побудовані на основі слова: розповідь, пояснення, опитування, обговорення, супроводження виконання вправи.

При використанні даного методу навчання особливу увагу приділяють точності і лаконічності діалогу з учнем. Слово повинно бути образним і точним, а вираз - коротким і зрозумілим. Вибір способу впливу словом в значній мірі залежить від віку і підготовленості учнів, а також від здібності викладача. Використання термінології полегшує спілкування між учнем і викладачем.

Метод показу. Даний метод допомагає створити уяву про вправу, уточнити окремі деталі техніки, звернути увагу учнів на допущені помилки, порівняти варіанти виконання вправи.

Один із способів показу заключається в демонстрації цілісного і досконалого виконання руху еталона техніки. Крім цього, можливий акцентований показ окремих фаз і фрагментів з виділенням вирішальних або типових моментів виконання руху.

При розучуванні гімнастичних вправ ефективним способом є опосередкований показ - демонстрація кінокільцівок, кінограм, наглядних малюнків, схем і других методичних посібників.

Метод цілісного розучування вправ. Він має на увазі виконання вправи в цілому. Таке оволодіння рухами характерно для більшості вправ основної гімнастики, для відносно простих рухів на приладах, а також для окремих складних вправ, які можуть бути виконані в цілому в полегшених умовах. Полегшені умови виконання вправ досягаються різними способами: 1) додатковими засобами безпеки; 2) наданням допомоги; 3) зменшенням висоти приладу.

Метод підводящих вправ. Він містить в собі цілісне виконання руху, раніш вивченого і структурно подібного до нового. Головним правилом використання є структурна подібність з вправою, якій навчають. Наприклад, для розучування підйому махом вперед використовується підводяща вправа підйом махом вперед 3 упору на передпліччях.

Метод розчленованого розучування вправ. Суть методу - виділення окремих частин руху, оволодіння кожною і поєднання їх в цілу вправу. Штучне дроблення вправи на частини полегшує оволодіння рухових дій. Кожна вправа повинна бути конкретною і доступною, а також не привносити принципових змін в структуру цілісного руху.

Метод вирішення окремих рухових задач. Метод характеризується підбором серії навчальних завдань, які містять компоненти техніки основної вправи. Даний метод використовується для уточнення уяв про техніку, виправлення стійких помилок, удосконаленню виконання вправи в цілому.

Метод термінової і поточної інформації про точність виконуваних рухів. Метод реалізується 3 допомогою методичних прийомів, таких як: додаткові орієнтири (термінова інформація), бінарна і цифрова інформація (поточна інформація). Додаткові орієнтири можуть бути визначені до виконання вправи. Введення орієнтирів допомагає уточнити виконання окремих частин вправи по ходу виконання вправи в цілому. Поточна інформація пред'являється учням в бінарній («більше-менше») або в цифровій формі. Більший вплив на якість повторного виконання має цифрова інформація.

Метод супряження. Метод містить в собі єдність фізичної підготовки і навчання рухам. Зміст і спрямованість вправ фізичної підготовки повинні відповідати структурі цільового навику і характеру м'язових зусиль.

Метод програмування. До методів програмування відноситься метод розпоряджень алгоритмічного типу (А.М. Шлемін). Під розпорядженням алгоритмічного типу в навчанні руховим діям слід розуміти точні, суворо визначені і доступні розпорядження про порядок і характер дій учнів для оволодіння тим чи другим рухом або групою їх, схожих за структурою.

При складанні розпоряджень алгоритмічного типу необхідного враховувати:

1) розпорядження повинні точно вказувати на характер кожної дії, виключати випадковість в їх виборі і бути доступними всім, кому вони призначені; 
2) розпорядження алгоритмічного типу можуть бути складені як для однієї рухової дії, так і для серії рухових дій, структурно схожих, але обов'язково доступних на даному етапі навчання;

3) всі навчальні завдання повинні бути взаємозв'язані різними варіантами залежності і мати послідовне ускладнення.

Розпорядження алгоритмічного типу передбачають розділ навчального матеріалу на частини (дози, порції або навчальні завдання) і навчання учнів цим частинам в сурово визначеній послідовності; при цьому тільки оволодіння першою серією навчальних завдань дає право переходити до другої. Порядок вивчення частин навчального матеріалу визначається наявністю зв'язку між ними. Відомо, що на фоні розвинених фізичних здібностей швидше і краще формуються рухові навики. Тому в першу серію навчальних завдань повинні входити вправи для розвитку тих фізичних здібностей, які необхідні для успішного виконання цільового навику. Друга серія навчальних завдань повинна включати вправи на оволодіння вихідних і кінцевих положень, якими починаються і закінчуються цільові вправи (перша і друга серія навчальних завдань можуть оволодіватись одночасно).

Третя серія навчальних завдань повинна передбачати дії, без яких неможливо виконати цільову вправу (розмахування в висі або в упорі, махові рухи ногами і т.д.).

Четверта серія навчальних завдань містить в собі діï, пов'язані з навчанням умінню оцінювати виконання рухів в просторі, за часом і рівнем м'язових зусиль. Кількість і рівень точності диференціровок залежать від координаційної складності цільової вправи. Інколи достатньо вміти оцінювати лише амплітуду маху і рівень м'язових зусиль, а при навчанні складним вправам необхідно вміти оцінювати комплекси диференціровок, які забезпечують технічну основу вправи.

П'ята серія навчальних завдань - підводящі вправи і частини цільового навику.

Шоста серія навчальних завдань - виконання вправи в цілому в полегшених умовах, з допомогою учителя та в з'єднанні з другими вправами.

При вивченні кожного навчального завдання враховуються індивідуальні особливості учнів та їх готовність до навчання, здійснюється контроль за виконанням навчальних завдань, визначається порядок переходу від одного до другого навчального завдання. При виконанні всіх серій навчальних завдань вирішуються задачі фізичної підготовки, навчання умінням керувати рухами і формування рухових навичків. Таким чином, в методі розпоряджень алгоритмічного типу поєднується фізична, спеціально-рухова і технічна підготовки.

Метод розпоряджень алгоритмічного типу не може розглядатись окремо від існуючих в гімнастиці методів і прийомів навчання, він спирається на них і в той же час доповнює і розширює їх. Наприклад, при проведенні вправ першої серії навчальних завдань, пов'язаних з спеціальною фізичною підготовкою, застосовується метод супряження; в другій серії - метод розчленованого розучування і прийом фіксації окремих положень; в третій - метод вирішення окремих рухових задач; в четвертій - метод термінової і поточної інформації про точність виконуваних рухів; в п’ятій - метод підводящих вправ і розчленування; в шостій - метод цілісного розучування․

Упорядковувати розпорядження алгоритмічного типу слід в такій послідовності:

1) вказати назву вправи;

2) описати техніку і привести кінограму;

3) вказати, що повинні знати і вміти учні перед виконанням вправи;

4) написати серії навчальних завдань.

\section{Методика навчання вправам на снарядах}

Під методикою навчання гімнастичним вправам на снарядах розуміємо сукупність методів та засобів для вирішення завдання уроку.

Ефективність навчання залежить від умов, які забезпечують формування рухових навичок. До таких умов належать:

Першою умовою утворення рухового навику $€$ формування домінуючого мотиву навчання.

Другою умовою є підкріплення правильного виконання вправи. Таким підкріпленням в навчанні гімнастичним вправам спромагається служити інформація, одержана від тренера про вчинену дію. Підкріпленням є і безпосереднє відчуття цього результату. Відомо, що позитивно підкріплена рухова дія забувається не так швидко, як невірно виконана вправа.

Третя умова - руховий досвід тих, хто займається. Як правило, новий навик виробляється на основі яких-небудь готових навиків, чим більше руховий досвід, тим швидше діється утворення нових зв'язків. Для розучування нових вправ необхідно створити таку базу у вигляді підготовчих і підводящих вправ.

Четверта умова. Формування рухових навиків залежить від умов, в яких діється навчання. Встановлено, що доцільно зберігати постійні умови в початковій фазі і фазі розвитку рухового навику. По мірі закріплення основних компонентів рухової дії доцільно змінювати умови навчання і вимагати виконання вивчених рухів в різноманітних варіантах.

П'ята умова - кількість повторень. Тільки на основі повторення можлива інформація в ЦНС від рухового апарату і інших аналізаторів про ефективність протікання рухів. Одержана інформація, як правило, хутко опрацьовується в корі великих півкуль, і багаточисельні поправки до 
точності, швидкості, міри зусиль можливі лише при достатній інформації, тобто при достатній кількості повторень. Мала кількість повторень не дає можливості одержати детальну інформацію від рухового апарату про якість руху, у той же час надмірна кількість повторень стомлює дітей, притупляє м'язове чуття.

Шоста умова - навчання рухам в дві сторони.

Сьома умова - навчання умінням управляти рухами в просторі, за часом і по мірі м'язових зусиль.

Восьма умова - перерва між виконанням вправ і між заняттями. Суттєвим питанням теорії і практики є визначення оптимальних перерв між повторенням вправи. В результаті досліджень встановлено, що помилка в точності виконання основних параметрів руху збільшується 3 тривалістю перерви після навчання, 3-хвилинна перерва не впливає на зміну навченості (М.М. Демідов, 1972).

Враховування тривалості перерви між заняттями відіграє важливу роль з точки зору збереження досягнутого рівня навченості. Так, А.В. Менхін (1970) відмічає, що при навчанні складному руху, на протязі перших 24 годин після навчання проходить збільшення числа успішних спроб виконання цього руху (процес засвоювання), а на протязі наступних - зниження даного показника (процес забування).

Проведені дослідження показують, що 48-годинна перерва в повторенні вправи з рівнем навченості $p=0,1-0,3$ значно збільшує тривалість початкового етапу формування рухового навику. При $p=0,6-$ 0,7; 0,8-1,0 в більшості випадків після перерви для відновлення початкового рівня навченості не потрібно додаткових вправ. Тобто по досягненні рівня навченості $\mathrm{p}=0,6-0,7 ; 0,8-1,0$ можливі перерви в повторюванні і перехід до навчання новим рухам. Раніше вивчені вправи необхідно періодично повторювати, тривалість перерви не повинна бути більшою за 1 місяць (О.М. Худолій, 1983, А.М. Шлемін, О.М. Худолій, 1982).

Дев 'ята умова - режим роботи і стан гімнастів. Режим роботи в занятті в значній мірі впливає на стан функціональних систем організму юних гімнастів. Оптимальний режим підвищує працездатність і сприяє більш ефективному навчанню. Так, після середніх навантажень найбільш тривалий етап розвитку рухового навику $(p=0,4-0,5$; 0,6-0,7). Після великих навантажень збільшується тривалість початкового етапу формування рухового навику. Чим складніша вправа, чим більших зусиль вона потребує, тим більше під дією великих навантажень збільшується тривалість початкового етапу формування рухового навику $(p=0,1-0,3)$ і етапу розвитку рухового навику $(p=0,4-0,5)$.

В результаті дослідження встановлено, що виконання юними гімнастками вправ на приладах в зоні зміни пульсу 140-160 уд/хв. приводить до втоми i, як наслідок, до погіршення якості виконання вправ на 0,3-0,6 бала; виконання вправ на приладах в зоні зміни пульсу 120-135 уд/хв. негативно не впливає на якість виконання вправ; виконання вправ в зоні зміни пульсу 100119 уд/хв. - сприяє підвищенню якості виконання вправи на 0,3-0,4 бала (О.В. Іващенко, 1988).

На основі вищевикладеного сформулюємо правила успішного навчання гімнастичним вправам:

1. ЯКЩО формування рухового навику, ТО роль мотивації послаблена i, навпаки, переважну роль відіграє вправа.

2. ЯКЩО вправі передує формування знань про принципи побудови руху, ТО результативність навчання рухам вища, можливий позитивний перенос навику.

3. ЯКШО вправа повторюється в занятті 6-12 разів, по 2-3 рази в підході, ТО відзначається зростання рівня навченості в занятті.

4. ЯКЩО перерва в повторенні не перевищує 3 хвилини, ТО тимчасовий зв'язок підкріпляється.

5. ЯКШО перерва між заняттями не перевищує 24 години, ТО навчання продовжується з більш високого рівня навченості.

6. ЯКЩО в період відпочинку між вправами учень здійснює уявний огляд пройденого, ТО наступні спроби більш ефективні.

7. ЯКЩО інтервал відпочинку дозволяє усунути втому (60-120 сек), ТО швидкість навчання зростає.

8. ЯКШО в ситуації навчання тривалість вправи збільшується (в одному підході виконується 4 і більше повторень), ТО втома, зниження швидкості навчання.

9. ЯКЩО процес утворення умовних реакцій, ТО виробляються вісцеральні умовні реакції серцева, дихальна, вазомоторна діяльність, газообмін піддаються обумовленню (Ле Ні Жан-Франсуа, 1973).

10. ЯКШО рівень розвитку рухового хисту відповідає характеристикам вправи, ТО швидкість навчання зростає, тривалість процесу навчання скорочується на 1/3.

11. ЯКЩО послідовне навчання рухам 3 подібними підготовчими фазами і різноманітними фазами основних дій, ТО навчання проходитиме швидше, чим при паралельному.

12. ЯКЩО в процесі навчання враховуються правила 1-11, ТО швидкість навчання зростає, тривалість процесу навчання скорочується на $1 / 3-1 / 2$.

Далі складемо програму навчання алгоритмічного типу для підйому махом вперед в упор на паралельних брусах.

\section{Техніка виконання вправи:}

В крайній точці маху назад, коли тулуб і ноги підіймуться вище жердин, потрібно округлити спину. По ходу маху вперед, перед вертикаллю, хльостоподібним махом прогнутися і пружно 
провисаючи в плечових суглобах, енергійно направити ноги вперед-вверх, згинаючись в кульшових суглобах (до $135^{\circ}$ ). Трохи раніше, чим ноги досягнуть рівня жердин, різко розігнутися, пригальмувати рух ніг, виконати енергійний ривок грудьми і відштовхнутися плечима від жердин. Натискуючи руками на жердини, перейти в упор, продовжуючи мах вперед (рис.).

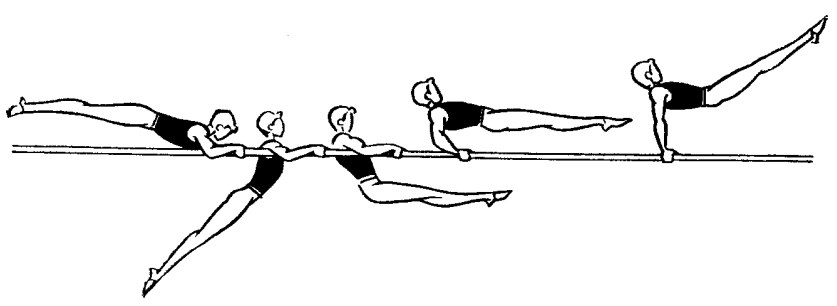

Навчальні завдання

Перша серія навчальних завдань:

1. Згинання і розгинання рук в упорі максимально швидко (5 раз за 3-4 сек).

2. 3 упору на руках ривком підйом в упор.

Друга серія навчальних завдань:

1. Фіксувати упор лежачи, ноги нарізно на брусах.

2. Упор на руках з додатковим вантажем з провисанням в плечах.

Третя серія навчальних завдань:

1. Розмахування в упорі на руках по максимальній амплітуді.

2. Розмахування в упорі на руках з акцентованою увагою, на хльост ногами вперед-вверх і активне відштовхування плечима від жердин.

Четверта серія навчальних завдань:

1. Розмахування в упорі на руках по заданій амплітуді.

2. Розмахування в упорі на руках з мінімальним збільшенням маху вперед.

3. Розмахування в упорі на руках з підльотом і мінімальним збільшенням маху вперед.

П’ята серія навчальних завдань

1. 3 упору махом назад зігнути руки, махом вперед випрямити.

2. 3 упору на передпліччях підйом махом вперед.

3. На похилих брусах підйом махом вперед в сід ноги нарізно.

4. Підйом махом вперед з допомогою.

5. Підйом махом вперед самостійно.

6. Підйом махом вперед - зіскок махом назад.

\section{Методика навчання загальнорозвиваючим вправам}

Особливістю виконання загальнорозвиваючих вправ на відміну від прикладних є стилізація рухів. До найбільш загальних вимог відносяться прямі руки і ноги, випрямлені носки, чіткі вихідні і кінцеві положення. В зв'язку з цим при прове- денні ЗРВ необхідно вказувати учням на відхили від даних норм.

ЗРВ мають порівняно невеликий обсяг. Але умови виконання (зміна вихідних положень, застосування предметів, приладів для виконання вправ у висах і упорах, використання партнера, який допомагає чи перешкоджує виконанню вправ, зміна напруженості та інтенсивності рухів, наявність складних взаємовідношень нервово-рухового апарату тощо) дають величезні можливості для утруднення і ускладнення їх.

При оволодінні ЗРВ застосовуються методи навчання в цілому і по розділенню. Застосовуються способи навчання за показом, розказом і комбінований.

1. Спосіб навчання в цілому за показом. Викладач спочатку показує вправу в цілому, потім подає команду «Вихідне положення прийняти!». Після цього подається команда «Вправу почи-НАЙ!». Викладач виконує вправу, стоячи перед групою, дзеркально, що значно полегшує виконання учнями вправи. ЗРВ рекомендується проводити під рахунок. Частіше це 4 і 8 рахунків. Це пов'язано 3 музикальним супроводженням.

При навчанні ЗРВ «за показом» одночасно даються вказівки, які рухи виконуються, на який рахунок. Закінчується вправа по команді «Стій!». Команда подається замість останнього відліку.

При навчанні дітей молодшого шкільного віку команди можуть замінятися на розпорядження: «Прийміть вихідне положення», «Виконуйте вправу, як я», «Закінчити вправу».

2. Спосіб навчання в цілому за розказом. Цим способом користуються при навчанні простим вправам або з метою активізувати увагу учнів. Викладач пояснює вправу, вказує вихідне положення і коротко пояснює, які рухи виконують на рахунок «один», «Два» і т.д.

Рекомендується по ходу підказувати основні діï замість підрахунку, але в ритмі і темпі вправи. Наприклад, замість «один-два-три-чотири» сказати: «Нахил-випрямитись-присістивстати».

3. Спосіб навчання «за розділенням». Цей спосіб використовується для навчання складним за координацією ЗРВ. Після команди «Вихідне положення прийняти!» викладач подає команди, розділяючи кожен відлік паузами. Наприклад: «Праву ногу назад на носок, руки вверх - виконуй раз!», «Упор присівши на лівій, праву в сторону - виконуй два!», «Змінити положення ніг - виконуй три!», «Вихідне положення - виконуй чотири!».

4. Навчання ігровим способом. Використання рухливих ігр та ігор типу естафет з виконанням в ігровій ситуації окремих загальнорозвиваючих вправ значно активізує рухову діяльність учнів.

Включення ігрових моментів в процес виконання вправ робить заняття більш емоційним, вправи виконуються з більшим захопленням. 
Слід також відмітити, що загальнорозвиваючі вправи можно виконувати повільно (на 3-4 відліки кожен рух) і швидко (на кожен відлік) і з максимальною швидкістю. Таким чином, цими завданнями можна навчати розрізняти швидкі рухи від повільних, тобто тривалість руху. Шляхом виконання загальнорозвиваючих вправ з великою, середньою і малою амплітудою можна навчати просторовій оцінці рухів. При цьому рекомендується одні і ті ж вправи виконувати повільно і швидко, по великій і малій амплітудах.

При виконанні загальнорозвиваючих вправ можна змінювати ступінь напруги м'язів - виконувати вправу з максимальними зусилями, впівсили і мінімальною напругою м'язів. Такі завдання виконуються 3 набивними м'ячами, гантелями.

Виконання загальнорозвиваючих вправ з завданнями, розрізняти тривалість руху, їх амплітуду і ступінь м'язових зусиль дає можливість навчати керувати рухами.

Дуже важливо, щоб одні і ті ж рухи виконувались то повільно, то швидко, з малою і тут же 3 великою амплітудою, а також з максимальним і мінімальним м'язовим зусилям. Контрастні за характером рухи дають можливість краще розрізняти і запам'ятовувати їх особливості.

Регулювання фізичного навантаження при заняттях ЗРВ здійснюється за рахунок зміни:

- кількості вправ;

- змісту вправ;

- інтервалу відпочинку між вправами (скорочення пауз для відпочинку збільшує навантаження);

- кількості повторів (як правило, кожну вправу повторюють 4, 8, 12, 16 раз);

- темпу (більш швидкий темп вправи, як правило, має і більше навантаження);

- вихідних положень.

Дозувати вправи потрібно, виходячи із загальних правил обліку ступеня готовності учнів, їх віку, статі і задач, які вирішуються з даним контингентом.

\section{Методика навчання прикладним вправам}

\section{Лазіння і перелізання}

Вправи в лазінні і перелізанні - активні рухові дії, виконання яких включає в роботу всі ланцюги рухового апарату. Наявність великої кількості прийомів в лазінні по різних гімнастичних приладах (під нахилом поставлених гімнастичних лав, гімнастичній стінці, канатах, шестах), перелізання через гімнастичну колоду, коня, козла, гірки матів - роблять ці вправи доступними для учнів всіх вікових груп.

На заняттях основною гімнастикою в молодших класах вправи в лазінні проводяться в змішаних упорах і висах. Лазіння в змішаних висах і упоpax виконується з меншою напругою, чим лазіння тільки на руках тому, що при виконанні лазіння в змішаних висах в роботі приймають участь руки, ноги і м'язи тулуба.

Враховуючи складність вправ в лазінні, необхідно проводити їх, починаючи з простих прийомів, таких як лазіння по гімнастичній лаві, поставленій під нахилом, гімнастичній стінці, похило і горизонтально підвішених канатах, а потім переходити до навчання прийомам лазіння по вертикальному канату.

\section{Навчання лазінню і перелізанню}

Прості способи лазіння і перелізання опановуються зразу після показу і пояснення. В окремих випадках можна застосовувати метод виконання за розділенням. Так, наприклад, при навчанні перелізанню через колоду або гімнастичного коня подаються такі розпорядження:

1 - стрибок в упор - виконуй раз!

2 - лягти на живіт і обхопити руками снаряд - виконуй два!

3 - перенести ноги через снаряд, повертаючись в сторону захвату руками снаряда і зіскочити 3 нього вперед в стойку боком до снаряда виконуй три!

Застосовуючи цей метод, можна швидко, без грубих помилок навчити дітей тим чи іншим руховим діям.

\section{Навчання лазінню по канату}

Лазіння по канату - найбільш складна вправа і без відповідної підготовки учню часто не вдається піднятися навіть на невелику висоту на канаті. Вправи в лазінні по канату потребують доброї силової підготовки і уміння поєднувати рухи руками і ногами.

Досвід роботи учителів з фізичної культури свідчить про те, що навчити дітей «цілісним» методом дуже важко. Для навчання учнів лазінню по канату рекомендується спеціально складена програма за принципом алгоритмічних розпоряджень. Крім цього, рекомендується починати навчання лазінню по канату способом у висі на зігнутих руках з захватом каната ногами.

\section{Лазіння в висі на зігнутих руках}

В.п. - вис на зігнутих руках.

1 - зігнути ноги вперед і захопити канат ногами схресно так, щоб зовнішня сторона стопи однієї ноги і внутрішня сторона гомілки другої тісно притискувались до каната; 2 - випрямляючи ноги, ще вище підтягнутись на руках i, зберігаючи захват каната ногами, по черзі перехватити руки вище так, щоб залишитись в висі на зігнутих руках.

Приступати до навчання потрібно з перевірки готовності учнів до оволодіння даною вправою:

1 - перевірити знання про те, що починати лазіння слід з вису на зігнутих руках, а захват каната ногами робити так, щоб стопа і гомілка тісно притискувались до каната;

2 - перевірити уміння виконувати вис на зігнутих руках (5-6 сек) на гімнастичній стінці і піднімати зігнуті ноги в висі 5-6 разів. 
Якщо ці вимоги виконуються, то можна приступити до навчання лазінню по навчальній програмі, приведеній нижче.

Перша серія навчальних завдань.

1. 3 вису на зігнутих руках на гімнастичній стінці, повільно розгинаючи руки, перейти в вис за 6-8 сек. Повторити $2-3$ рази.

2. Те ж, але утриматись в висі на зігнутих руках 4-5 сек.

3. 3 вису на гімнастичній стінці підняти зігнуті ноги вперед якомога вище і опустити в в.П. Повторити $8-10$ разів.

4. 3 вису сидячи, ноги нарізно на канаті, перейти в вис лежачи, з почережним перехватом рук у вис стоячи. Повороти 2-3 рази.

Друга серія навчальних завдань.

1. 3 вису стоячи на канаті, відштовхуванням ніг прийняти положення вису на зігнутих руках на канаті і висіти на протязі 4-5 сек. Повторити 2-3 рази.

2. Сидячи на гімнастичній лаві, захопити ногами гімнастичну палку, імітуючи захват каната. При вірному захваті палка повинна утримуватись вертикально.

3. Сидячи на гімнастичній лаві, захопити канат ногами так, як було описано вище.

4. 3 вису на зігнутих руках захватити канат ногами і утримувати це положення 5-6 сек.

Третя серія навчальних завдань.

1. 3 вису стоячи на зігнутих руках захопити канат ногами i, розгинаючи ноги, перехопити руки вище. Повернутись в в.П. Повторити $2-3$ рази.

2. Те ж, але після випрямлення ніг перехопити руки вище і повернутись у в.п. Повторити $2-3$ рази.

Четверта серія навчальних завдань.

1. Те ж, що друга вправа третьої серії, але після перехвату рук, згинаючи ноги, захопити ними канат вище і повернутись в в.п. Повторити 2-3 рази.

2. Те ж, але виконати $2-3$ перехвати руками і ногами і повернутись в в.п.

3. Те ж, але виконати 4-5 перехватів.

4. Лазіння по канату на 2 м і повернення.

5. Лазіння по канату на задану відстань: хлопчики -3 м, дівчатка -2 м.

\section{Лазіння в три прийоми}

В.п. - вис на прямих руках. 1 - зігнути ноги вперед і захватити канат ногами (підйомом однієї і п'яткою другої ноги); 2 - не ослабляючи захвату ногами, розігнути їх (відштовхуючись) і зігнути руки; 3 - по черзі перехопити руки вверх і прийняти в.П., не відпускаючи захвату каната ногами.

Лазіння в три прийоми застосовується в заняттях 3 жіночими групами та групами дітей середнього шкільного віку, так як навантаження падає не тільки на м'язи рук і плечового поясу, але і на м'язи ніг. При навчанні цьому способу лазіння потрібно добре оволодіти прийомами лазіння на вертикальній драбині.

Для полегшення засвоєння прийомів лазання на канаті рекомендуються такі вправи:

1. а) вис на канаті на прямих руках і розкачування в висі; б) вис після відштовхування ногами або з невеликого розбігу.

2. Розучування захвату ногами, сидячи на лаві.

3. Захват ногами каната в положенні вису на прямих руках.

4. 3 вису сидячи на підлозі ноги нарізно, підтягуючись і спираючись п'ятами об підлогу, вис лежачи на зігнутих руках.

\section{Лазіння в два прийоми}

$\mathrm{E}$ два варіанти лазіння по канату в два прийоми.

Перший варіант. В.п. - вис на прямій руці, друга рука тримає канат на рівні підборіддя. 1 згинаючи ноги вперед, захватити канат, як при лазіння в три прийоми; $2-$ розгинаючи ноги (відштовхуючись), підтягнутись на одній руці, а другою перехопити канат вгорі.

Другий варіант. В.п. - вис на прямих руках. 1 - підтягуючись на руках, зігнути ноги і захватити ними канат; 2 - розгинаючи ноги (відштовхуючись), перехопити канат руками, тобто перейти в вис на прямих руках.

Цей спосіб лазіння координаційно нескладний, тому при достатній фізичній силі оволодіти ним нескладно.

Для полегшення засвоєння прийомів лазіння на канаті рекомендуються вищеприведені вправи.

\title{
ОБҐРУНТУВАННЯ ЕФЕКТИВНОСТІ МЕТОДУ КОНТРОЛЮ ФІЗИЧНОГО НАВАНТАЖЕННЯ У ДІТЕЙ-АКСЕЛЕРАТІВ ПО СУБ'ЄКТИВНИМ ВІДЧУТТЯМ ПРИ ЗАНЯТТЯХ БАСКЕТБОЛОМ НА УРОКАХ ФІЗКУЛЬТУРИ В ШКОЛІ
}

\author{
Викладачі кафедри спортивних ігр Ж.Л. Козина, \\ М.А. Вакслер, А.О. Тихонова \\ Харківський державний педагогічний університет \\ ім. Г.С. Сковороди
}

Сучасний процес навчання в школі характеризується високим інтелектуальним і емоційним навантаженням [3, 4]. Уроки фізкультури в школі ста- ють для більшості дітей практично єдиним засобом підтримки мінімального рівня фізичної активності, необхідного для нормального функціонування орга- 